\title{
Challenges for Achieving Competitiveness in the EU Automotive INDUSTRY
}

\author{
Márcio Rodrigues $^{1}$; Beatriz Mendes ${ }^{2}$; Eva Š́rová ${ }^{3}$ \\ 1,3 Technical University of Liberec, Faculty of Economics, \\ Department of Business Administration and Management, \\ Studentská 1402/2, 46117 Liberec, Czech Republic \\ ${ }^{2}$ State University of Campinas (Unicamp), São Paulo, Brazil \\ e-mail: ${ }^{1}$ marcio.rodrigues@ tul.cz; ${ }^{2}$ beatriz.fmendes22@ gmail.com; ${ }^{3}$ eva.sirova@tul.cz
}

\begin{abstract}
A clear understanding of customer's needs is an essential aspect in the pursuit of competitiveness in companies. Answering the question which one delivers the best product or service becomes harder as the time flows, as all of them are in pursuit of achieving the same goal: truly understand how the market behaves. It is a fact that competitiveness and benchmarking process among automotive companies are challenging in a stable global economic scenario. How would those processes look like in a global economic crisis? Which challenges will companies have to address in order to be competitive in this scenario? This article presents a case study of a global automotive supplier and the challenges it faced during the 2008-2009 economic crisis over statistical analysis of its demand and downtimes, where many lessons learned from this scenario could be studied for better prediction and handling future ones.
\end{abstract}

\section{Keywords}

Benchmarking; Competitiveness; Automotive industry; Global financial crisis.

\section{Introduction}

The question which company delivers the best product or provides the best service becomes harder as the time flows, as all of them are in pursuit of achieving the same goal: truly understand which the customer's needs are. Due to the evolution of humanity and its faster means of knowledge dissemination throughout the globe, those demands become more complex to fulfill, as products and services need to be more customizable, adaptable and, at the same time, reliable, robust and with great quality evaluation. These aspects seem to be very subjective when different markets are analyzed but there is certainly one aspect that needs to be taken into consideration so that a product, a service and, consequently, a company be competitive: the lowest selling price possible. And taking it deeper into the production or aggregate value chain, the statement becomes a matter of who actually delivers the lowest cost possible.

In order to compare companies of a same market, the process of benchmarking has been used since its first publication in 1989, where the ones which are rated as market leaders or detain the biggest market share or also considered a reference according to a determined comparison parameter (e.g. Quality control, cost, lead time, reliability, robustness, service level and others) set the level for the other competitors (Delbridge, 1995 et al). It also provides support for comparison of different plants and processes of one company, finding possible gaps and improvement opportunities within the production processes. 
Leading the discussion to the automotive industry, competitiveness and benchmarking processes are even more sensible, as its processes and products have a high complexity level and a huge impact on the world economy (Žižka, 2016). It's not only a matter of which company has the lowest production costs, but also a very detailed quality control program (mostly implemented with Total Quality Management), maintenance of production machinery and aftersales, spare parts control, internal and external logistics, administration of the supply chain and a very important, key aspect: the environmental impact (Sulírová et al., 2017). Clearly, it's not a simple process to determine which automotive brand would be called as the "best-in-class". It's mainly a matter of which parameter(s) is (are) taken into consideration for comparison. Another important aspect worth mentioning is the geographical effect of the market, which is deeply related to the customer profile. Despite the fact that automotive market widens its global effect each year, it would be accurate to compare equally how competitive a vehicle is in different markets without understanding customer's car preferences? It would deliver inaccurate information for the company.

All those approaches properly address the fact that competitiveness and benchmarking process between automotive companies are challenging in a stable global economic scenario. How would those processes look like in a global economic crisis? Which challenges must companies address in order to be competitive in this scenario?

To understand this question, this paper brings an analysis of which challenges an automotive supplier from European Union (EU) faced during the 2008-2009 global crisis in its maintenance process.

Before focusing on the company's data, it's necessary to understand the impacts of the global economic crisis on the automotive industry presented in the next chapter of this paper.

The paper is divided into five sections. Chapter 1 shows relevant literature research regarding benchmarking and competitiveness. Chapter 2 presents relevant information about the studied company. Chapter 3 brings conclusions and future possible works from this research.

\section{$1 \quad$ Brief Literature Review: Benchmarking}

Since the early 80's the concept and application of the benchmarking process have been studied and published in literature, including the discussion of Xerox Corporation practices comparing operational costs between US and Japanese plants (Delbrige et al, 1995). The concept was originally adopted by the Westinghouse Productivity and Quality Care, when Xerox won the Malcolm Baldrige National Quality Award in 1989. It correlates the pursuit of better practices to improve competitive performance, quoted as:

"Benchmarking is a continuous search for an application of significantly better practices that lead to superior competitive performance." (Camp, 1989)

During the 90's and early 2000's, a few publications discussed the concept brought in 1989, bringing guidelines, relationship with practicability, improvement opportunities resulting from the benchmarking process. Dattakumar (2003) presents these perspectives over the concept shown in Table 1. 
Tab. 1: Outcome of earlier literature reviews

\begin{tabular}{|l|l|l|}
\hline$\#$ & Paper Title & Outcome \\
\hline 1 & $\begin{array}{l}\text { "Roadmap to current } \\
\text { benchmarking literature", by } \\
\text { Jackson et al. (1994) }\end{array}$ & $\begin{array}{l}\text { The paper gives a guideline for the classification of } \\
\text { literature on benchmarking, based on the types of } \\
\text { benchmarking and associated issues and comments } \\
\text { on each article in terms of these criteria }\end{array}$ \\
\hline 3 & $\begin{array}{l}\text { "Review of key publications } \\
\text { part II", by Zairi and Youssef } \\
\text { (1995c, 1996) }\end{array}$ & $\begin{array}{l}\text { The papers spell out in detail about the contents of } \\
\text { only books on benchmarking in terms of the } \\
\text { practicability and applicability of the resource } \\
\text { material. Publications in journals and conferences are } \\
\text { omitted in this paper }\end{array}$ \\
\hline $\begin{array}{l}\text { "Benchmarking: a select } \\
\text { bibliography", by Vig (1995) }\end{array}$ & $\begin{array}{l}\text { The paper is targeted towards personnel in libraries, } \\
\text { to enable them to track author wise classification of } \\
\text { articles on benchmarking }\end{array}$ \\
\hline $\begin{array}{l}\text { "A framework for } \\
\text { benchmarking in the public- } \\
\text { sector literature review and } \\
\text { directions for future research", } \\
\text { by Dorsch and Yasin (1998) }\end{array}$ & $\begin{array}{l}\text { In the paper, the authors have identified that the } \\
\text { academic community is lagging in terms of providing } \\
\text { and advancing models and frameworks that integrate } \\
\text { the many facets of organizational benchmarking. The } \\
\text { authors also mention that most of the benchmarking } \\
\text { know-how available are the results of practitioners } \\
\text { efforts. }\end{array}$ \\
\hline $\begin{array}{l}\text { "The theory and practice of } \\
\text { by Yasin (2002) }\end{array}$ & $\begin{array}{l}\text { The paper summarizes that despite the increasing } \\
\text { scope of benchmarking activities and the number of } \\
\text { organizations utilizing benchmarking, the field of } \\
\text { benchmarking remains to a large extent without a } \\
\text { unifying theory to guide its advancement. Also, a call } \\
\text { is given to developing innovative methodologies to } \\
\text { guide benchmarking practices in e-commerce and } \\
\text { supply chain management }\end{array}$ \\
\hline
\end{tabular}

Source: Adapted from Dattakumar (2003)

Recent publications explore the definition of a framework (Deros et al. 2006), bringing the need of a set of parameters or aspects delimiting the benchmarking process, i.e. the base data for comparison between companies (e.g. lowest lead-time, highest service level, biggest Mean Time Between Failures (MTBF) and others). Deros et al. (2006) present some models for generic benchmarking processes (as cited in Spendolinni, 1992 and NPC, 1999), where the main steps for their implementation are explained, as shown in Figures 1a and 1b. The first one shows in a PDCA-like cycle the phases and their benefits of the comparison process. The second one is a flowchart of the main phases of this process. 

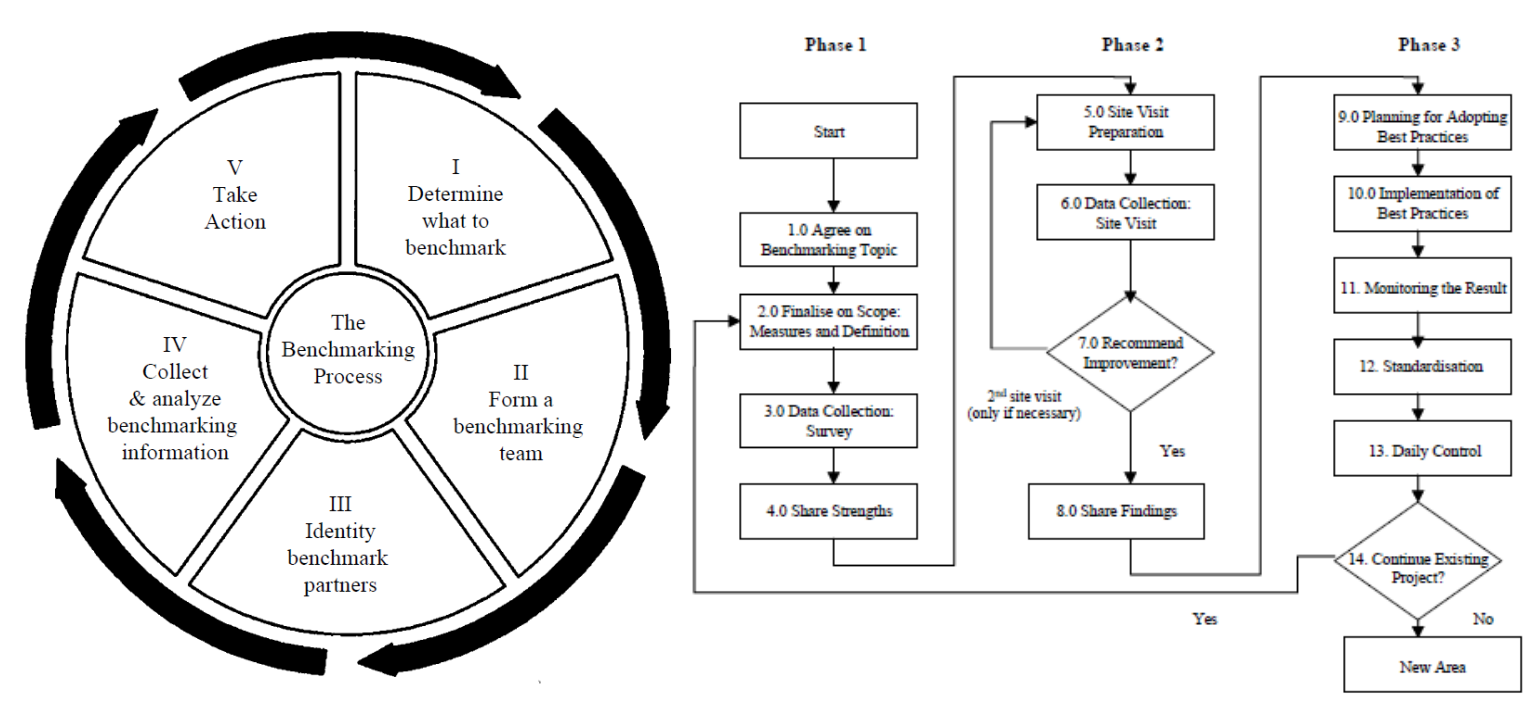

Source: Baba (2006) (as cited in Spendolinni 1992 and NPC 1999)

Fig. 1: $a$ (left) and $b$ (right): Models for the benchmarking process

Other authors bring classification and differentiation inside the benchmarking process (Freytag and Hollesen, 2001), giving it a better practical and applicable approach. They divide the whole process into three main definitions:

- Benchmarking as an independent growing process of efficiency, which relies on analysis of performance levels of what is in examination compared to other levels inside the organization and identification of root causes of performances problems to proper guide corporate activities reconfiguration (as cited in Kruteen 1999);

- Benchlearning associated with the previously mentioned "best-in-class" company or object in order to absorb those practices in all company, also known as "learn from the best" and

- Benchaction as the work plan for implementation of all changes obtained from benchmarking and benchlearning, and also to improve employees with training and development.

Freytag and Hollesen (2001) also define some types of benchmarking, depending on what the company wants to compare:

- Internal: related to processes and units that have similar functions, identifying the best internal practices and expanding to the other units;

- Industry (also called by the authors as functional): This is an internal or external comparison, which measures the company's functional operations and then compares to similar measures from other companies, mostly with market leaders or which detains the biggest market share. It's also not a direct competition, mostly intended to share information for processes improvements within a market or multinational company;

- Competitive: External comparison used against direct competitors, in order to change the market share between them, pointing failures and advantages of concurrent products and services. Information is harder to be obtained from this process and generally involves high costs and

- Process (also called as generic by the authors): this one compares similar procedures at dissimilar companies and it's very hard to implement, because it needs a very solid and 
broad understanding of process and procedures, in order to extrapolate to other markets or industries.

They also compare advantages and disadvantages of the benchmarking process within and across industries, shown in Table 2.

Tab. 2: Advantages and disadvantages of benchmarking within and across industries

\begin{tabular}{|l|l|}
\hline Benchmarking within the industry & Benchmarking across industries \\
\hline $\begin{array}{l}\text { Advantages: similarity of the competitive } \\
\text { situation eases the transfer of experience }\end{array}$ & $\begin{array}{l}\text { Advantages: inspiration to improve processes, } \\
\text { etc. In which areas are the advantages best } \\
\text { and/or easy to realize }\end{array}$ \\
\hline $\begin{array}{l}\text { Drawbacks: the perception of the } \\
\text { competitive situation is too narrow which } \\
\text { makes it difficult to catch up with other } \\
\text { companies as regards competition }\end{array}$ & $\begin{array}{l}\text { Drawbacks: it is difficult to transfer } \\
\text { experience across industries. Perhaps } \\
\text { eliminate focus from the obvious problems in } \\
\text { the company }\end{array}$ \\
\hline
\end{tabular}

Source: Adapted from Dattakumar (2003)

\section{Results of the Research}

\subsection{The Studied Company}

Due to confidentiality, the name of the company won't be presented in this article. However, for this research, the data analyzed on next subchapters were obtained from a global automotive exterior parts supplier, mostly from its activities in the Czech Republic operations facilities. According to its 2016 annual report, it registered a net revenue of US\$ 2.78 billion, with more than 155,000 employees allocated in 29 countries around the world.

The Czech facility is responsible for production and assembly of front and rear bumpers, energy management systems, polycarbonate modules, spoilers for aerodynamics and many other parts inside a vast product portfolio for the global automotive market.

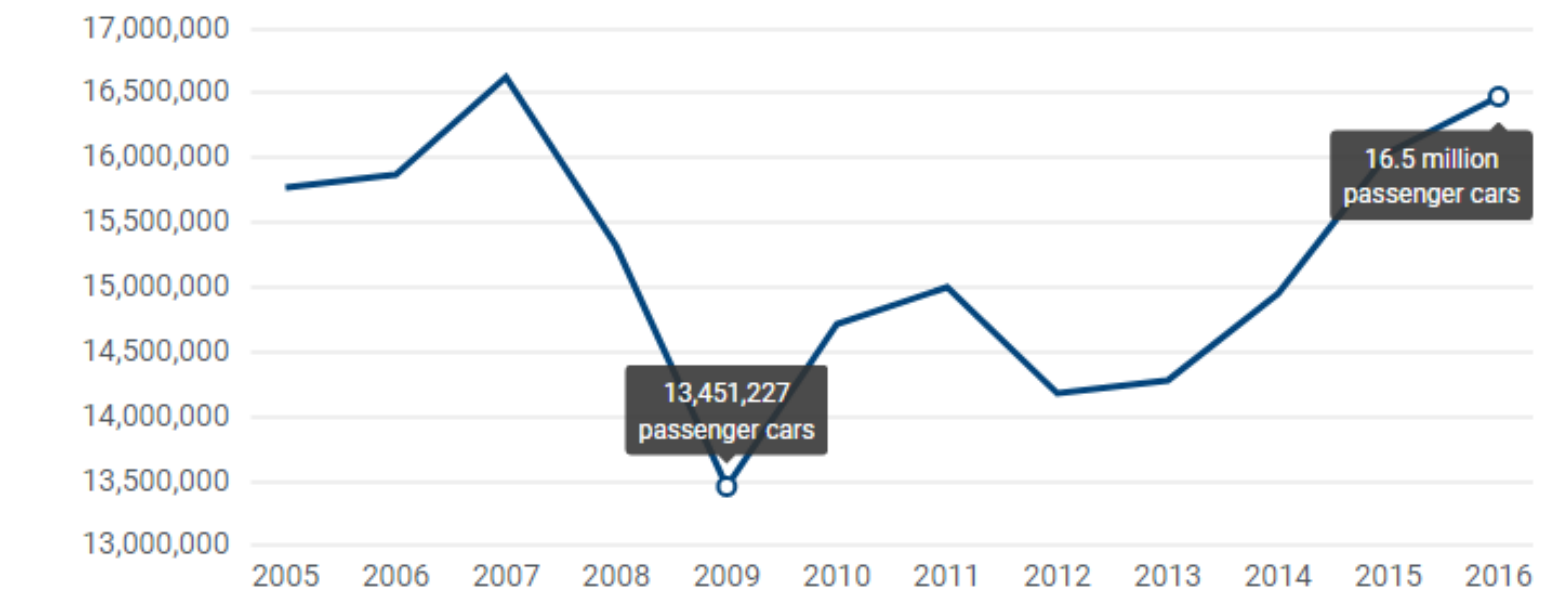

Source: AIE (2016)

Fig. 2: Comparative demand for passenger cars in European Market

As the demand of passenger cars has substantially decreased in 2009 and reached the lowest value in the horizon of the last 10 years, as shown in Figure 2 for the whole European market, many challenges have appeared to its operation: stock management and its increased cost, as predicted demand was expected to be much bigger, a new pattern for seasonal demand, increase of machinery non production and many others, bringing the company a big reduction 
of its net revenue by the end of the year as a reflex of this global crisis and increasing of variable and fixed costs. In the next subchapter the main focus of the case study is described in detail.

\subsection{Research Objectives}

The data analysis conducted by the statistical SW Minitab aims to check the statistical correlations between some parameters in the automotive industry, such as seasonal demand and stoppage time. It is important to highlight that the conclusions presented here are related to the year of 2009, which, as said before, was a turbulent period for the world and also the European automotive industry.

\subsection{Discussion}

In Figure 3 below, it is possible to observe that the number of maintenance, which is strongly related to problems occurred in-line production, probably due to demand. It is clear to observe that maintenance at the beginning and at the end of the year is quite lower than the rest of the year, also it is not varying close to the mean, as the other results. It is important to highlight that the data provided for January start on the day 26, so many data are probably lost or the production faced a long recession.

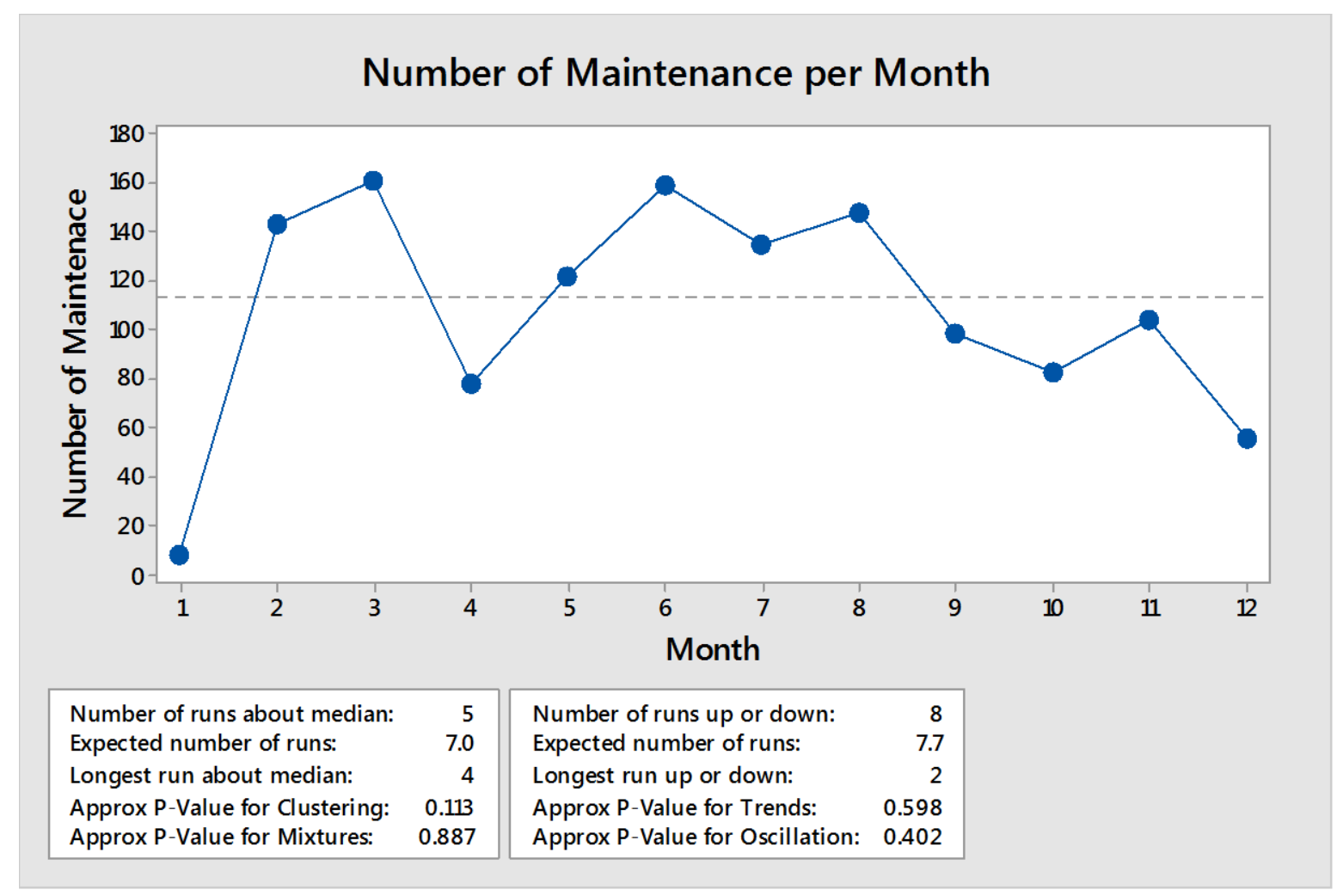

Source: Own

Fig. 3: Number of maintenances per month in 2009

Besides the number of maintenance for January and December are not close to the mean, as it can be observed in Figure 4, they are still into the confidence level of 95\%. It means that the process is in steady-state - $p$-value for oscillation is above alpha of 0.05 - and there are no outliers in this production line. So, for this period of time, special causes can be neglected. This fact is justified by the p-value for clustering above alpha value. Also, variation in number of maintenance shows a downward trend from month $6-p$-value for trends of $0.598-$ which 
can be caused by implementation of a better production control of equipment or decrease in production.

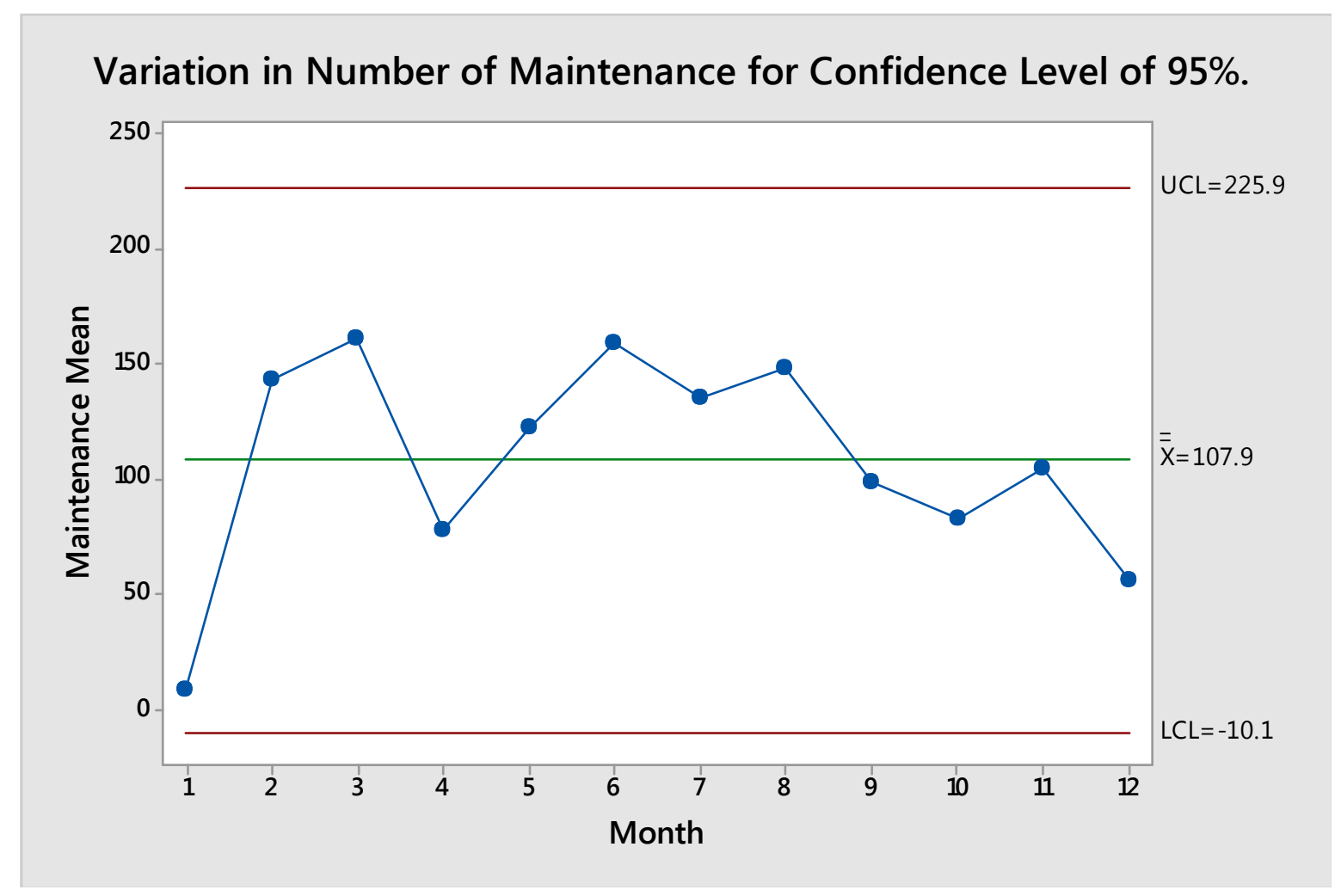

Source: Own

Fig. 4: Variation in number of maintenance for a confidence level of $95 \%$ in 2009

In order to complete the evaluation of these data, a normality test was conducted and the results are shown in Figure 5. As the data are not far from the fitted distribution line (red line) and the p-value is higher the alpha value, the null hypothesis, which the data do not follow a normal behavior, can be neglected by lack of information to prove it. However, it's not possible to affirm that it presents a normal behavior.

It is also important to analyze the duration of each maintenance, since it affects the profits and probably the whole production chain. Figure 6 shows the variation in time for each month. In January, the variation occurs due to the lack of date, which means that the data will not converge to the mean value, as the other results.

In relation to months from February to December, the duration of maintenance time varies approximately to a mean. When the January data are excluded, it is possible to note that the variation in maintenance time is approximately of 100 minutes. 


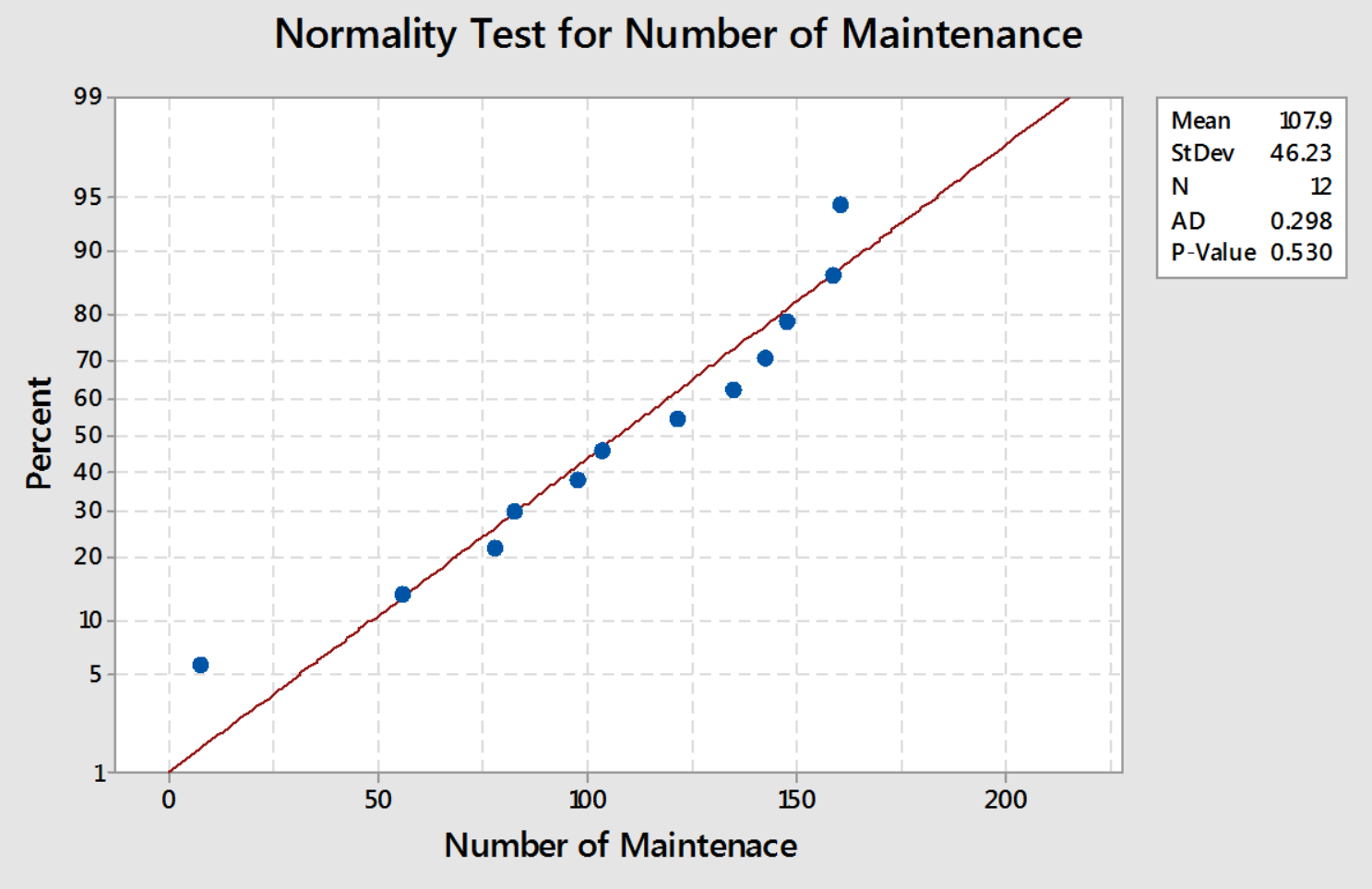

Source: Own

Fig. 5: Normality test for number of maintenance in 2009

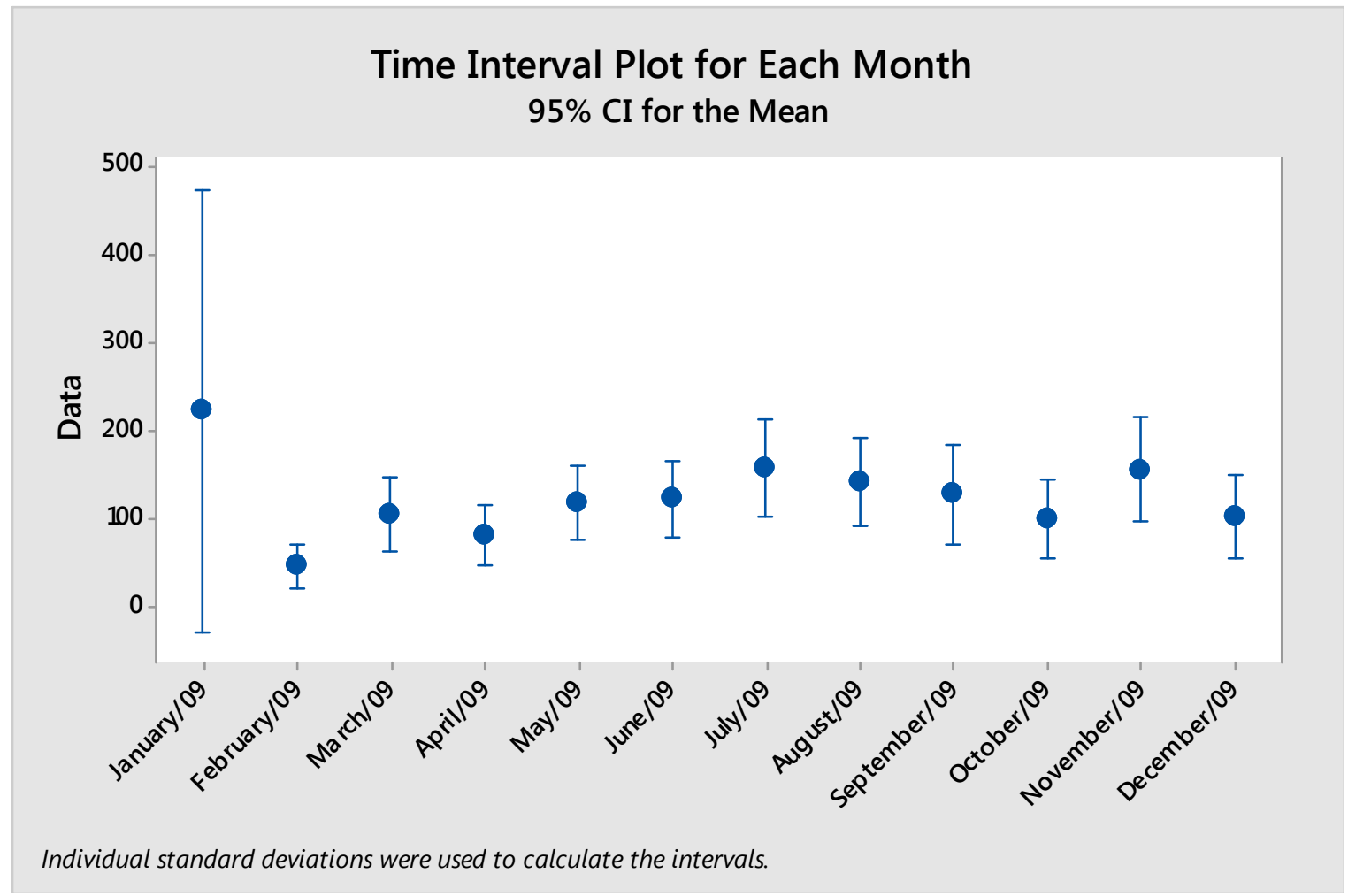

Source: Own

Fig. 6: Interval plot for maintenance time for each month in 2009 


\section{Conclusion}

This article has been intended to discuss and present challenges faced by companies from the automotive sector during the 2008-2009 global crisis, focusing on the European Market. Chapter 1 explores relevant concepts on the benchmarking process, presenting ongoing and past models and explanation of its fundamentals. Chapter 2 presents the main contribution of this article, discussing the effects of the crisis in a global automotive supplier company in Europe, presenting some statistical analysis over seasonal demand and stoppage time.

After a brief introduction and a literature review of relevant concepts and topics of benchmarking, it is clear that achieving competitiveness is a constant need for major multinational companies, especially in a crisis scenario, where available resources are at its lower level, costs at higher, demand as minimum as ever and many operational problems come ahead to make this process even harder.

What is important to sustain is that all lessons learned that came from intermittency and seasonal effect of demand in a crisis environment are even more sensitive than a regular economic scenario and serve as a base for improvement of demand forecast and prediction patterns for the future. Who knows when the next economic crisis comes? It's not $100 \%$ guaranteed to predict, but it is definitely necessary to be ready when it comes again.

Future research on the topic discussed in this article is possible, as individual aspects of maintenance, size of stocks, demand forecast and so on and so forth can be discussed based on the data collected for this article, as a consequence of how relevant it is to understand the effects of a global economic crisis from all perspectives in companies and its impact and challenges for achieving competitiveness.

\section{Acknowledgements}

This article was supported by SGS 21301 "Project Management and Information Systems in Quality and Supply Chain Management" provided by Technical University of Liberec, Czech Republic

\section{Literature}

[1] DEROS, B. M.; YUSOF, S. M.; SALLEH, A. M.: A benchmarking implementation framework for automotive manufacturing SMEs. Benchmarking: An International Journal. 2006, 13(4), 396-430. DOI: 10.1108/14635770610676272

[2] BARTRAM, S. M.; BODNAR, G. M.: No place to hide: The global crisis in equity markets in 2008/2009. Journal of International Money and Finance. 2009, 28(8), 12461292. DOI: $10.1016 /$ j.jimonfin.2009.08.005

[3] DATTAKUMAR, R.; JAGADEESH, R.: A review of literature on benchmarking. Benchmarking: An International Journal. 2003, 10(3), 176-209. DOI: $\underline{10.1108 / 14635770310477744}$

[4] DELBRIDGE, R.; LOWE, J.; OLIVER, N.: The process of benchmarking. International Journal of Operations \& Production Management. 1995, 15(4), 50-62. DOI: $10.1108 / 01443579510083604$

[5] FREYTAG, P. V.; HOLLENSEN, S.: The process of benchmarking, benchlearning and benchaction. The TQM Magazine. 2001, 13(1), 25-34. DOI: $\underline{10.1108 / 09544780110360624}$ 
[6] JO, H.; KIM, J.; PARK, J.; YANG, H.; PARK, H.: Study on Cycle Time Reduction of Injection Molding Using CAE. Technical Paper 2017-01-0489. In: $W C X^{\mathrm{TM}}$ 17: $S A E$ World Congress Experience. 2017, SAE International, United States. ISSN 0148-7191. e-ISSN 2688-3627. DOI: $10.4271 / 2017-01-0489$

[7] SULÍROVÁ, I.; ZÁVODSKÁ, L'; RAKYTA, M.; PELANTOVÁ, V.: State-of-the-art Approaches to Material Transportation, Handling and Warehousing. Procedia Engineering. 2017, 192, 857-862. DOI: 10.1016/j.proeng.2017.06.148

[8] YASIN, M. M.: The theory and practice of benchmarking: then and now. Benchmarking: An International Journal. 2002, 9(3), 217-243. DOI: $\underline{10.1108 / 14635770210428992}$

[9] ŽIŽKA, M.; BUDAJ, P.; MADZÍK, P.: The Adequacy of an Organisation's Measurement System in Quality Management. Quality - Access to Success. 2016, 17(155), 60-67. Available from https://www.academia.edu/30371371/The_adequacy_of_an_organisation_s_measureme nt_system_in_quality_management 


\section{VÝZVY K DOSAŽENÍ KONKURENCESCHOPNOSTI V AUTOMOBILOVÉM PRŮMYSLU}

$\mathrm{V}$ EU

Pokud firmy chtějí být konkurenceschopné, základním požadavkem je jasné pochopení potřeb zákazníka. Odpověd’ na otázku, která firma nabízí nejlepší produkt nebo službu, se v průběhu času ztíží, protože všechny se snaží dosáhnout stejného cíle: pochopit, jak se trh doopravdy chová. Je skutečností, že proces konkurence a srovnávání kvality mezi automobilovými společnostmi je ve stabilním globálním ekonomickém scénáři náročný. Jak by tyto procesy vypadaly v globální hospodářské krizi? Jaké výzvy budou firmy muset řešit, aby byly v tomto scénáři konkurenceschopné? Tento článek představuje př́padovou studii globálního automobilového dodavatele a problémy, kterým čelil během ekonomické krize v letech 20082009, týkající se statistické analýzy jeho poptávky a prostojů. Ze získaných zkušeností se lze poučit a lépe předpovídat a řešit problémy v budoucnosti.

\section{HERAUSFORDERUNGEN ZUR ERLANGUNG DER KONKURRENZFÄHIGKEIT IN DER AUTOMOBILINDUSTRIE IN DER EU}

Wenn die Firmen konkurrenzfähig sein wollen, müssen sie die Bedürfnisse des Kunden klar im Blick haben. Die Antwort auf die Frage, welche Firma das beste Produkt oder die beste Dienstleistung anbietet, fällt im Laufe der Zeit immer schwerer, weil alle versuchen, das gleiche Ziel zu erreichen, nämlich zu begreifen, wie sich der Markt tatsächlich verhält. Es ist eine Tatsache, dass der Prozess der Konkurrenz und der des Vergleichens der Qualität unter den Automobilgesellschaften in einem stabilen globalen ökonomischen Szenarium anspruchsvoll ist. Wie sähen diese Prozesse in einer globalen Wirtschaftskrise aus? Vor was für Herausforderungen werden die Firmen gestellt, um in einem solchen Szenarium konkurrenzfähig bleiben zu können? Dieser Artikel bietet eine Fallstudie eines globalen Automobillieferanten und schildert die Probleme, mit denen er es während der ökonomischen Krise in den Jahren 2008-2009 zu tun hatte und welche die statistische Analyse ihrer Nachfrage und Ausfallzeiten betreffen. Aus den gewonnen Erfahrungen kann man Lehren ziehen und die Probleme in der Zukunft besser vorhersehen und lösen.

\section{WYZWANIA DLA OSIĄGNIĘCIA KONKURENCYJNOŚCI W PRZEMYŚLE MOTORYZACYJNYM W UE}

Jeżeli firmy chcą być konkurencyjne, to podstawową przesłanką jest jasne zrozumienie oczekiwań klienta. Odpowiedź na pytanie, która firma oferuje najlepszy produkt lub usługę, z biegiem czasu staje się utrudniona, ponieważ wszystkie starają się osiągnąć ten sam cel: zrozumieć, jak rynek naprawdę się zachowuje. Faktem jest, że proces konkurencji i porównywania jakości pomiędzy przedsiębiorstwami motoryzacyjnymi jest w stabilnym globalnym scenariuszu ekonomicznym trudny. Jak by procesy te wyglądały w czasie globalnego kryzysu gospodarczego? Przed jakimi wyzwaniami będą stały przedsiębiorstwa, by przy takim scenariuszu zachować konkurencyjność? W niniejszym artykule przedstawiono studium przypadku globalnego dostawcy samochodów oraz problemy, z jakimi borykał się w czasie kryzysu gospodarczego w latach 2008-2009. Obejmuje ono analizę statystyczną popytu na jego produkty i przestojów. Ze zdobytych doświadczeń można wyciągnąć wnioski, by lepiej przewidywać i rozwiązywać problemy w przyszłości. 